\title{
THE LAW OF INTERNATIONAL CIVIL PROCEDURE IN CHINA
}

\author{
Li Shuangyuan* and Lü Guoming**
}

\section{INTRODUCTION}

Although differing in regard to the relationship between private international law and the law of international civil procedure, ${ }^{1}$ almost all Chinese legal scholars define the latter as a body of rules binding the courts and the litigating and other parties involved when dealing with civil and commercial cases involving foreign elements. They hold that it is made up of three principal components: (a) the rules regulating the status of the litigating foreign nationals, foreign countries and international organizations in civil proceedings; (b) the rules concerning the jurisdiction of courts over international civil and commercial cases; (c) the rules governing the taking of evidence abroad, the

\footnotetext{
* Professor of Law, Hunan Normal University and Wuhan University.

** $\mathrm{PhD}$ candidate, Wuhan University.
}

The authors wish to thank Mr. ZHANG MAO for his kind assistance in the course of writing this piece.

${ }^{1}$ Some Chinese scholars regard the law on international civil procedure as a separate branch of law, while others are of the opinion that it is just a sub-division of private international law. The following definitions are from two scholars who take contrasting attitudes:

(1) "International civil procedure law and private international law are closely connected, but they are two branches of law of different nature. Private international law, which is substantive law, governs the substantive rights and obligations of the parties in international civil and commercial legal relationships, whereas the law on international civil procedure is procedural law which determines the procedural rights and obligations of parties in international civil litigation. The subjects of private international law relationships in most cases are two parties, while in an international civil procedure there is always a third party involved, i.e. the court or another judicial organ with jurisdiction to adjudicate." XIE SHISONG, 'Guoji Minshi Susongfa Shi Yige Duli de Falü Bumen' [The science of the law on international civil procedure as an independent legal discipline], Law Review (1996, no. 5) 38-42.

(2) "Traditional private international law also covers international civil procedure. In view of the close connection between private international law and international civil procedure law - i.e. the rules of civil procedure applicable to cases with foreign elements - it is suitable to include the latter into, and regard it as a component of, private international law . . . until it constitutes an independent branch of law." YU XIANYU, Jianmin Guoji Sifaxue [A concise treatise on the science of private international law] (Beijing; 1986) 362.

Discussions on the relationship between international civil procedure law and private international law can also be found in other books and articles, such as Li SHUANGYUAN, Guoji Sifa [Private International Law] (Wuhan; 1987) 29-30; LIU ZHENJIANG, ZHANG ZHONGBO and YUAN CHENDI (eds), Guoji Sifa Jiaochen [A Course of Private International Law] (Lanzou; 1988) 8; QIAN HuA (ed.), Guoji Sifa [Private International Law] (Beijing, 1992) 441-442.

Asian Yearbook of International Law, Volume 6 (Ko Swan Sik et al., eds.

- Kluwer Law International; printed inthe Netherlands), pp. 135-167 
proof of foreign laws, the preservation of property rights, the service abroad of judicial and extrajudicial documents in civil and commercial matters, and the recognition and enforcement of foreign judicial decisions and arbitral awards. ${ }^{2}$

Since the adoption of the policy of opening to the outside world in 1978, the Chinese legislature, the people's courts (especially the Supreme People's Court), the Chinese legal profession and legal scholars have paid increasing attention to the law of international civil procedure. In less than ten years, two statutes on the law of civil procedure have been promulgated, both of which include a part entitled "Special Provisions on Civil Procedure in Cases Involving Foreign Elements". ${ }^{3}$ Since the 1980s, and especially in recent years, Chinese scholars have published numerous articles and several monographs on international civil procedure law. ${ }^{4}$ This has pushed scholarship in the field of the Chinese law on international civil procedure to a new stage and has been of great help to the Chinese legislature and Chinese legal practice. A brief introduction to the principles and new developments of international civil procedure law in China will be provided below.

\footnotetext{
${ }^{2}$ See HAN DEPEI (ed.), Guoji Sifa [Private International Law] (Wuhan; 1983) 418; XIE SHISONG, loc.cit. n. 1 p. 38. A newly published law textbook written by LI HAOPEI lists the following six topics within the law on international civil procedure: immunities from civil and commercial adjudication; adjudication jurisdiction over international civil and commercial cases; the legal status of foreigners in the law of international civil procedure; recognition and execution of foreign civil and commercial judgements; international civil and commercial judicial assistance; international civil and commercial arbitration. LI HAOPEI, Guoji Minshi Chengxufa Gailun [An Introduction to the Law of International Civil Procedure] (Beijing, 1996) 5.

${ }^{3}$ The two statutes are the Provisional Law of Civil Procedure of the PRC, adopted by the 22nd session of the Standing Committee of the Fifth National Congress on 8 March 1982 and abrogated on 9 April 1991, and the Law of Civil Procedure of the PRC (hereinafter CPL) which was both adopted and entered into force on 9 April 1991.

${ }^{4}$ Almost all books on private international law published in China contain a part on international civil procedure. See e.g., YAO ZHUANG and REN JISHEN, Guoji Sifa Jichu [Basic knowledge of private international law] (Beijing, 1981) 209; HAN DEPEI, op.cit. n. 2, p. 373; LI SHUANGYUAN (ed.), Guoji Sifa [Private International Law] (Beijing, 1991) 437. At the end of 1996 there were six monographs on the law on international civil procedure: LIU ZHENJIANG, Guoji Minshi Susongfa Yuanli [The Basic Principles of International Civil Procedure Law] (Beijing, 1985); LI SHUANGYUAn and XIE SHISONG, Guoji Minshi Susongfa Gailun [An Introduction to International Civil Procedure Law] (Wuhan, 1990); LI YUQUAN (ed.), Guoji Minshi Susong He Guoji Sangshi Zhongcai [International Civil Procedure and International Commercial Arbitration] (Wuhan, 1994); JiN PENGNIAN, Guoji Minshi Chengxufa [International Civil Procedure Law] (Hangzhou, 1995); XIE SHISONG, Guoji Shangshi Zhongcai He Guoji Minshi Susongfa [International Commercial Arbitration and International Civil Procedure Law] (Guangzhou, 1995); LI HAOPEI, op.cit. n. 2.
} 


\section{GENERAL CONTEXT}

\subsection{The judicial system}

\subsubsection{Structure}

As a unitary state, China has one general judicial system. All judicial organs apply uniform substantive and procedural laws throughout the country, unless the law provides otherwise. ${ }^{5}$ The organization of the judicial system of the People's Republic of China (PRC) is laid down in the Law on the Organization of the People's Courts of the PRC, which was adopted at the second session of the Fifth National People's Congress (NPC) on 1 July 1979, and amended at the second session of the Sixth NPC on 2 September $1983 .{ }^{6}$ Article 2(1) of the law provides that "the judicial authority of the PRC is exercised by the following people's courts: (a) local people's courts at various levels; (b) military courts and other special people's courts; (c) the Supreme People's Court". Paragraph 2 of the same sub-divides the local people's courts according to level, into 'basic people's courts', 'intermediate people's courts', and 'higher people's courts'.

Basic people's courts are county people's courts and municipal people's courts, people's courts of autonomous counties, and people's courts of municipal districts. ${ }^{7}$ Intermediate people's courts are those established in prefectures of a province or an autonomous region and in municipalities which fall directly under the central government, namely Beijing, Shanghai and Tianjin. There are also intermediate people's courts of municipalities which come directly under the jurisdiction of a province or an autonomous region and of autonomous prefectures. ${ }^{8}$ Higher people's courts include those of provinces, autonomous regions, and municipalities which fall directly under the central government. ${ }^{9}$ The Supreme People's Court, located in Beijing, is the highest judicial organ of the PRC. ${ }^{10}$ It supervises the administration of justice by local people's courts at various levels and by special people's courts. ${ }^{11}$ It also renders interpretations in case of questions concerning specific applications of laws and decrees in judicial proceedings. ${ }^{12}$

\footnotetext{
${ }^{5}$ Hongkong and Macao will be two exceptions to China's general judicial system. According to the Sino-British Joint Declaration on the question of Hongkong and the Sino-Portuguese Joint Declaration on the question of Macao, the two regions will keep their judicial systems unchanged for at least fifty years after 1997 and 1999 respectively.

${ }^{6}$ Chinese text in Fagui Huibian [Collection of Laws] 47-51; English translation in Statutes and Regulations, code No. 790705.1.1.

${ }^{7}$ Law on the Organization of the People's Courts of the PRC, Art. 18.

${ }^{8}$ Ibid., Art. 23.

${ }^{9}$ Ibid., Art. 26.

${ }^{10}$ Ibid., Art. 30(1).

${ }^{11}$ Ibid., Art. 30(2).

${ }^{12}$ Ibid., Art. 33.
} 
In addition to military courts, which are provided for in Article 2(2) of the Law on the Organization of the People's Courts, there are some other special people's courts which have jurisdiction in particular fields. These include, for instance, railway courts and maritime courts. The position of the special people's courts runs parallel with that of intermediate people's courts.

Under the Law of Civil Procedure (CPL), a collegiate court is the general rule and single-judge courts are the exception. Article 40 of the CPL provides that the people's court of first instance shall try civil cases by a collegiate panel composed of judges with or without judicial assessors. The collegiate panel must have an odd number of members. ${ }^{13}$ Single-judge courts operate only in civil cases under a summary procedure. ${ }^{14}$

In civil cases, adjudication by the people's courts takes place in two instances. ${ }^{15}$ A party has the right to file an appeal against a judgment of first instance with the people's court at the next higher level. The judgment of the latter people's court shall then be final. The CPL, however, also lists some special cases where no appeal to a higher court is allowed and where the judgment of first instance is final. ${ }^{16}$ These comprise the following four categories: cases concerning the qualification of voters; cases concerning a declaration of a person as missing or dead; cases on the adjudgment of the legal incapacity or the restricted legal capacity of persons; and cases on the determination of property as being without an owner.

\subsubsection{Competent courts dealing with civil litigation involving foreign elements}

As there are no special courts for transboundary civil matters in China, every people's court is competent to hear cases in international civil litigation. Besides, the CPL does not distinguish between cases involving foreign elements and those without such elements as far as jurisdiction is concerned. Therefore, civil cases involving foreign elements may, in first instance, fall under the jurisdiction of the people's courts of different levels, including the basic people's courts.

\subsubsection{The scheme of civil procedure}

In China, parties may choose among three methods to resolve their disputes, namely, mediation, arbitration and litigation. ${ }^{17}$ The third method is the most effective one. Where the parties are unwilling to submit their dispute to mediation, or have not included an arbitration clause in their contract, or have not made an arbitration agreement upon the emergence of the dispute, they can

\footnotetext{
${ }^{13}$ CPL, Art. 40(1).

${ }^{14}$ Ibid., Art. 40(2).

${ }^{15}$ Ibid., Art. 10.

${ }^{16}$ Ibid., Ch. 15 (Arts. 160-176).

${ }^{17}$ See CAI FABANG, Minshi Susongfa [Civil Procedure Law] (Beijing, 1992) 1-2.
} 
bring a lawsuit to a people's court. Provided the lawsuit fulfils the requirements stipulated by law, the court entertains the case and renders a judgment based on the facts and the law. This stage is called the procedure of first instance, which is roughly divided into the following stages: bringing a lawsuit and entertaining a case, preparations for trial, trial in court, suspension and termination of litigation, judgment and orders. ${ }^{18}$ In case of an appeal with the people's court at the next higher level, the people's court of second instance may, in the form of a judgment, reject the appeal or render its own decision (thereby replacing the judgment of first instance with one of its own), or remand the case to the original people's court for retrial. The judgment of a people's court that has become final is to be enforced either by the parties themselves or by an execution authority.

In addition to the procedures of first and second instance, the CPL provides for the procedure of 'trial supervision' which offers the possibility of a retrial in case of a judgment which is legally effective but in which definite errors have been found.

In trying civil cases the courts are under strict time limits which are clearly stipulated in the CPL. In procedures of first instance the courts are prescribed to conclude the proceedings of ordinary cases (as distinguished from simple cases) within six months after the entry of the case in the court's docket. Where lengthening of the period is necessary because of special circumstances, a six-month extension may be allowed subject to the approval of the president of the court. ${ }^{19}$ For simple cases, the time period is fixed at three months. ${ }^{20}$ In the procedure of second instance, the people's court shall conclude the proceedings within three months, with a possible extension of the period whenever necessitated by special circumstances subject to approval by the president of the court. ${ }^{21}$ The time period for special cases ${ }^{22}$ is similar to that of simple cases of first instance.

\subsubsection{Lex fori}

Article 4 of the CPL states that "whoever engages in civil litigation within the territory of the People's Republic of China must abide by this law". Consequently, the Chinese people's courts will exclusively follow the procedure as laid down by Chinese procedure law when dealing with both domestic civil actions and those involving foreign elements. The conclusion can thus be drawn that China, like many other countries, adheres to the principle of lex fori in matters of procedural law. Many Chinese scholars view the application of the lex fori as based on the principle of sovereignty.

\footnotetext{
${ }^{18}$ CPL, Ch. 12.

${ }^{19} \mathrm{CPL}$, Art. 135.

${ }^{20} \mathrm{CPL}$, Art. 146

${ }^{21}$ CPL, Art. 159.

${ }^{22}$ See supra 1.1.1.
} 


\subsection{The sources}

Unlike the practice in most common law countries, decisions of Chinese courts are not regarded as a source of Chinese law. ${ }^{23}$ The sources of the Chinese law on international civil procedure can be conveniently sub-divided into two categories: national sources containing domestic legislation and interpretation of laws, and international sources, mainly consisting of multilateral conventions and bilateral agreements. ${ }^{24}$

\subsubsection{National legislation}

There is no special statutory law on international civil procedure in China. The provisions on the subject are to be found scattered among the following various laws and regulations:

\section{A. The Civil Procedure Law}

This law was adopted at the fourth session of the Seventh NPC on 9 April 1991 and became effective on the same day ${ }^{25}$ It is composed of four Parts, 29 Chapters and 270 Articles. Part Four ("Special Provisions on Civil Procedure in Actions Involving Foreign Elements", Arts. 237-269) lays down the fundamental provisions of the law on international civil procedure. Its main contents include: General Principles (Chapter 24); Jurisdiction (Chapter 25); Service and Time Periods (Chapter 26); Property Preservation (Chapter 27); Arbitration (Chapter 28) and Judicial Assistance (Chapter 29).

\section{B. Regulations on Diplomatic Privileges and Immunities}

The "Regulations of the People's Republic of China on Diplomatic Privileges and Immunities" were adopted at the seventeenth session of the Standing Committee of the Sixth National People's Congress (NPCSC) and became effective as of the date of its promulgation, 5 September 1986. This law, consisting of 29 Articles, defines the diplomatic privileges and immunities of diplomatic missions in the PRC and their members. Indeed, in essence it serves public international law purposes. However, it also plays an important role in international civil procedure as it contains rules on issues of civil procedure involving persons enjoying diplomatic privileges and immunities. ${ }^{26}$

\footnotetext{
${ }^{23}$ Nevertheless most Chinese scholars acknowledge that the decisions of the Supreme People's Court play an important role in the development and improvement of the Chinese legal system.

${ }^{24}$ Some Chinese scholars also regard international custom to be a source of international civil procedure law. See Jin Pengnian, op.cit. n. 4, p. 13.

${ }^{25}$ CPL, Art. 270. This article simultaneously abrogated the 1982 Provisional Civil Procedure Law. Cf. supra, n. 3.

${ }^{26}$ The provisions on civil procedural issues of persons enjoying diplomatic privileges and immunities include Arts. 14 and 15. Art. 14(2, 3 and 4) reads: "[A diplomatic agent] shall [. . .]
} 


\title{
C. Regulations on Consular Privileges and Immunities
}

\author{
This act came into force on 30 October 1990. It also contains some provi- \\ sions on international civil procedure. ${ }^{27}$
}

enjoy immunity from civil and administrative jurisdiction, except in case of: (1) an action relating to succession in which he is involved as a private person; (2) an action relating to any professional or commercial activity conducted by him in the PRC outside his official functions in violation of sentence three of Article 25 of this law.

Execution shall not be enforced against a diplomatic agent with the exception of a forcible execution resulting from the circumstances referred to in the previous paragraphs of this Article, and provided that the measures of execution do not constitute any violation of his person and residence.

A diplomatic agent is not obliged to give evidence as a witness."

Art. 15(1 and 3) provides: "The immunity from jurisdiction of diplomatic agents and of persons who enjoy immunity under Art. 20 may be waived through expliexpression [of such waiver] by the government of the sending state.

The initiation of proceedings by a diplomatic agent or by a person who enjoys immunity from jurisdiction under Art. 20 shall preclude him from invoking immunity from jurisdiction with respect to any counter-claim which is directly connected with the claim.

Waiver of immunity from civil or administrative jurisdiction shall not imply waiver of immunity with respect to execution of a judgment, for which a separate and explicit waiver shall be required."

${ }^{27}$ These provisions include:

Art. 14: "Consular officers and members of the consular administrative and technical staff shall enjoy immunity from judicial and administrative jurisdiction with respect to acts performed in the exercise of their functions. The immunity from jurisdiction of consular officers with respect to acts other than those performed in the exercise of their functions, shall be handled according to bilateral treaties and agreements between China and the foreign state or on the basis of reciprocity.

The immunity from judicial jurisdiction enjoyed by consular officers and members of the consular administrative and technical staff does not apply to civil actions involving:

1. a contract which was not concluded expressly as an agent of the sending state;

2. private immovable property within the territory of China other than immovable property which is owned in the person's capacity as an agent of the sending state and is used for the consular post;

3. the inheritance of an estate, brought in a private capacity; or

4. damage arising from an accident caused by a vehicle, vessel, or aircraft within the territory of China."

Art. 15: "Members of a consular post may be required to act as a witness in the course of judicial or administrative proceedings, but are under no obligation to give evidence concerning matters connected with the exercise of their functions. They are entitled to decline to give evidence as expert witnesses with regard to the law of the sending state. to him.

If a consular officer declines to give evidence, no coercive measure or penalty may be applied

Members of the consular administrative and technical staff or of the consular service staff may not decline to give evidence except for matters connected with the exercise of their functions."

Art. 16: "The sending state may expressly waive the immunity from jurisdiction enjoyed by the staff as provided for in these Regulations.

The initiation of proceedings by a person who enjoys immunity from jurisdiction under these Regulations shall preclude him from invoking immunity with respect to any counterclaim directly connected with the principal claim.

The waiver of immunity from civil or administrative jurisdiction shall not entail a waiver of immunity from execution of a judgment. With respect to such an execution, a separate express waiver by the sending state will be necessary." 


\subsubsection{Treaties}

Treaties to which China is a party are regarded as a component of Chinese domestic law. In case of conflict the provisions of the treaty shall prevail. ${ }^{28}$ Since the 1980s, China has become a party to an increasing number of treaties, both multilateral and bilateral ones. Some of them relate to international civil procedure. The multilateral treaties among them comprise the New York Convention on the Recognition and Enforcement of Foreign Arbitral Awards of 10 June 1958 and the Hague Convention on the Service Abroad of Judicial and Extrajudicial Documents in Civil or Commercial Matters of 15 November 1965. On 2 December 1986, the Standing Committee of the Sixth NPC ratified the New York Convention. Ratification took place with the following two reservations:

(1) "The People's Republic of China will apply the Convention, only on the basis of reciprocity, to the recognition and enforcement of arbitral awards made in the territory of another Contracting State"; and

(2) "The People's Republic of China will apply the Convention only to differences arising out of legal relationships, whether contractual or not, which are considered as commercial under the national law of the People's Republic of China."

The principle of reciprocity, better known in China as the principle of 'mutual benefit', is much emphasized by Chinese authors as being one of the fundamental principles of private international law. ${ }^{29}$ It is regarded as a prerequisite for Chinese judicial assistance. As to the meaning of the concept 'contractual and non-contractual legal relationships of a commercial nature', the Supreme People's Court rendered a ruling specifying its scope..$^{30}$

\footnotetext{
${ }^{28}$ Although there is no pertinent provision in the Chinese Constitution on the relation between Chinese domestic law and the treaties to which China is a party, provisions of this kind can be found in some separate laws. E.g. Art. 142(2) of the General Provisions of Civil Law (see n. 58) stipulates: "If any international treaty concluded or acceded to by the People's Republic of China contains provisions differing from those in the civil laws of the PRC, the provisions of the international treaty shall apply, unless the provisions are ones on which the PRC has made a reservation." Article 238 of the CPL reads: "If an international treaty concluded or acceded to by the PRC contains provisions that differ from provisions of this Law, the provisions of the international treaty shall apply, except those in respect to which China has made a reservation".

${ }^{29}$ See HAN DEPEI, op.cit. n. 2, p. 32; YU XIANYU, op.cit. n. 1, pp. 23-24; YAO ZHUANG and REN JISHENG, op.cit. n. 4 p. 19; JIN PENGNIAN, op.cit. n. 4 p. 16.

${ }^{30}$ In its "Circular on the Implementation of the International Convention on the Recognition and Implementation of Foreign Arbitration Awards" of 10 April 1987 the Supreme People's Court stated that the so-called contractual and non-contractual commercial legal relationships are generally understood to be relationships of economic rights and duties arising from contract, tort or other relevant legal provisions, on topics such as the purchase and sale of goods, lease of property, contracts on projects or processing, transfer of technology, joint-ventures, equity joint ventures, prospecting and extraction of natural resources, insurance, loans, labour services, agencies, consultation services, the carriage of passengers and goods by sea, air, rail and road, product
} 
On 2 March 1991 the Standing Committee of the Seventh NPC ratified the Hague Service Convention of 1965. This was the first Convention concluded under the auspices of the Hague Conference on Private International Law that was ratified by the PRC after it had become a member of the Conference on 3 July 1987. Participation in this Convention was regarded conducive to international cooperation in the field of judicial assistance on a wider scope and, also, as furthering the role of China in the Hague Conference on Private International Law. ${ }^{31}$ In order to better implement the Convention in China, the Supreme People's Court, the Ministry of Foreign Affairs and the Ministry of Justice jointly issued two circulars, entitled "Certain Procedures in the Implementation"[of the Convention] (4 March 1992) and "Enforcement Measures on the Implementation" [of the Hague Service Convention] (19 September 1992).

Besides the above two conventions, China is a party to some other treaties containing provisions relating to international civil procedure ${ }^{32}$ As far as bilateral agreements are concerned, China, up to March 1996, had signed nineteen agreements on judicial assistance in civil, commercial and/or criminal matters. ${ }^{33}$ The majority of these agreements contain provisions on the following matters: fundamental principles, the scope of civil, commercial and/or criminal matters,${ }^{34}$ the designation of authorities who are to carry out the assistance, the law applicable to the assistance, the procedures to be followed in case of judicial assistance and provisions governing specific issues, such as the exemption of documents from authentication, the exchange of information, the entry into force and the termination of the agreement.

\subsubsection{Judicial interpretations and rulings by the Supreme People's Court}

The "Resolution Providing for an Improved Interpretation of the Law", adopted by the NPCSC on 10 June 1981, vested the competence of judicial interpretation in the judicial organs, enabling the courts to elaborate on laws

liability, environmental pollution, maritime incidents and disputes regarding ownership. However, they do not include disputes between foreign investors and local governments.

${ }^{31}$ People's Daily (Overseas Edition), 26 February 1991 p. 4.

${ }^{32}$ Such as the Vienna Convention on Diplomatic Relations of 18 April 1961, the Vienna Convention on Consular Relations of 24 April 1963, the International Convention on Civil Liability for Oil Pollution Damage of 29 November 1969, the Convention on International Civil Aviation of 7 December 1944, etc.

${ }^{33}$ These countries are: France (signed 4 May 1987 and entered into force 2 Aug 1988); Poland (5 Jun 1987 and 13 Feb 1988); Mongolia (31 Aug 1989 and 29 Oct 1990); Romania (16 Jan 1991 and 22 Jan 1993); Russian Federation (19 Jun 1992 and 14 Nov 1993); Belarus (11 Jan 1993 and 29 Nov 1993); Spain (2 May 1992 and 1 Jan 1994); Ukraine (31 Oct 1992 and 19 Jan 1994); Cuba (24 Nov 1992 and 26 Mar 1994); Italy (20 May 1991 and 1 Jan 1995); Egypt (29 Jul 1994 and 31 Mar 1995); Bulgaria (2 Jun 1993 and 30 Jun 1995); Kazhakstan (14 Jan 1993 and 11 Jul 1995); Belgium (signed 20 Nov 1987); Thailand (signed 16 Mar 1994); Turkey (28 Sep 1992 and 26 Oct 1995); Greece (signed 17 Oct 1994); Cyprus (25 Apr 1995 and 11 Jan 1996); Hungary (signed 9 Oct 1995).

${ }^{34}$ Most of the agreements cover civil and commercial matters. Only a few of them relate to civil, commercial as well as criminal matters. 
while applying the law in specific cases. The Supreme People's Court has issued many interpretations and rulings concerning laws and treaties on various issues of international civil procedure. These interpretations and rulings are also a source of the Chinese law on international civil procedure.

A striking example of judicial interpretation by the Supreme People's Court are the "Opinions on Certain Matters Relating to the Implementation of the Civil Procedure Law", issued on 14 July 1992 and including 18 Parts and 320 Articles. Part 18 (Arts. 304-320) deals with questions concerning civil cases involving foreign elements. Most of the articles specify the contents of related articles of the CPL, with only a few of them touching on new issues not covered by the CPL. ${ }^{35}$

In connection with the establishment of maritime courts, ${ }^{36}$ the Supreme People's Court in 1989 issued the "Stipulations of the Supreme People's Court Regarding the Acceptance of Cases by Maritime Courts". These Stipulations entered into force on 13 May 1989 and listed forty-two categories of maritime cases that were determined to fall under the jurisdiction of the maritime courts. They concerned maritime torts, maritime contracts, maritime commercial matters including general average, execution and preservation in regard to ships.

On 31 January 1986, the Supreme People's Court issued "Specific provisions on jurisdiction of maritime litigation involving foreign elements", which are regarded as the most comprehensive regulation specifically dealing with the jurisdiction of Chinese courts over cases involving foreign elements. These provisions consist of seventeen Articles and establish two or more connecting factors for each of the sixteen kinds of maritime legal actions in regard to which the maritime courts have jurisdiction. Article 17 further explicitly prescribes that the maritime courts may exercise jurisdiction over maritime lawsuits involving the following foreign elements:

(a) the defendant has his domicile, habitual residence, main business office, or permanent agency within Chinese territory;

(b) a Chinese maritime court has - for the purpose of preserving rights of a maritime nature - seized a foreign vessel at the request of the alleged holder of the right, or a party has provided a guarantee in China;

(c) the foreign defendant has property in China which could be seized;

(d) the parties have agreed to submit the dispute before a Chinese court.

Since the 1980s, the Supreme People's Court has also issued numerous replies, notices and letters, some of which are concerned with questions of

\footnotetext{
${ }^{35}$ E.g., Art. 310 states that the People's Court may make a written judgment upon the parties' request after having reached a settlement by conciliation (i.e. settlement on the basis of mediation).

${ }^{36}$ In accordance with the "Decision concerning the establishment of maritime courts in China's coastal harbour cities" (adopted by the Sixth NPC on 14 November 1984) and the "Decision concerning the establishment of maritime courts" (issued by the Supreme People's Court on 28 Nov. 1984), China has set up nine maritime courts in the following harbour cities: Guangzhou, Shanghai, Wuhan, Qingdao, Tianjin, Dalian, Haikou, Xiamen and Ningbo.
} 
international civil procedure. ${ }^{37}$ Chinese scholars differ in their views regarding the nature of these replies, notices and letters. Some treat them as sources of law, others hold the opposite view. Finally, the Supreme People's Court has ruled on the implementation of certain conventions on international civil procedure to which the PRC is a party. ${ }^{38}$

\footnotetext{
${ }^{37}$ The replies, notices and letters made or issued by the Supreme People's Court (SPC) comprise: (1) Circular of the SPC on the use of answer-back instruments for mutually entrusting the service of legal documents between China and Japan; (2) Official reply of the SPC according to which in case of a defendant resident abroad who was served a petition by public notice and who failed to enter an appearance, the judgment must be communicated by public notice; (3) Letter of the SPC on the question as to whether a request from a Chinese-American to file an appeal with Chinese courts can be granted; (4) Official reply of the SPC concerning litigation documents involving foreigners and the service of these documents after the case has been put on record; (5) Official reply of the SPC as to whether a reconciliation agreement can be formulated and issued to Japanese who had stayed in China as war orphans, later returned to their homeland, subsequently were sued for divorce by their spouses in China and whose case was settled through mediation by Chinese courts; (6) Letter of the SPC on the question whether, pursuant to Chinese law, the validity of a divorce between Chinese citizens who live abroad and who concluded a separation agreement in accordance with the laws of the country where they reside, can be recognized; (7) Official reply of the SPC as to whether staff members of a foreign embassy in China may act in their official capacity in briefing Chinese lawyers to act on behalf of their countrymen in civil lawsuits; (8) Official reply of the SPC as to whether foreign parties to a case before a Chinese court can be permitted to entrust foreigners residing in China or staff members of their country's embassy in China to act as their agents; (9) Official reply of the SPC on how to determine the statute of limitations for appeal in civil cases involving foreign interests in which one party lives in China and the other lives abroad; (10) Official reply of the SPC concerning the divorce case involving YIE LILI and LIANG WENRUI, a Chinese couple with Venezuelan citizenship; (11) Official reply of the SPC as to whether Chinese courts are entitled to take cognizance of cases involving a Chinese citizen who lives abroad and who has lodged appeals both with Chinese and foreign courts; (12) Official reply of the SPC on the handling of cases involving divorce decrees sent to Chinese people's courts directly by American courts and not through diplomatic channels; (13) Specific provisions of the SPC on the jurisdiction over maritime cases involving foreign interests; (14) Circular of the SPC, the Ministry of Foreign Affairs, and the Ministry of Justice on certain matters concerning Chinese and foreign courts entrusting each other with service of legal documents through diplomatic channels; (15) Regulations of the SPC on procedures for Chinese citizens in applying for recognition of divorce judgments rendered by foreign courts. The instruments issued by the SPC are published in Zhonghua Renmin Gongheguo Zuigao Renmin Fayuan Gongbao [Gazette of the SPC of the PRC].

${ }^{38}$ When a treaty in which China participates as a party has come into force, the Chinese government or the SPC in most cases would issue a notice or some other instrument on the implementation of the treaty in China. With regard to international civil procedure, the following notices should be heeded: (1) Notice of the SPC on the implementation of Sino-foreign judicial assistance agreements; (2) Notice of the SPC, the Ministry of Foreign Affairs, and the Ministry of Justice on certain procedures in the implementation of the Convention on the Service Abroad of Judicial and Extrajudicial Documents in Civil and Commercial Matters; (3) Notice of the SPC on the implementation of the Convention on the Recognition of Foreign Arbitral Awards.
} 


\section{JURISDICTION}

\subsection{The notion of jurisdiction}

Jurisdiction in international civil procedure refers to the scope of judicial power to which a country is entitled under international law. Jurisdiction over international civil cases is more complex than that over domestic civil cases. It involves two questions. ${ }^{39}$ One concerns the distribution of jurisdictional competence over international civil cases among related countries. The other refers to the distribution of jurisdiction over international civil cases among the courts of different levels and among those of the same level at different places in the same state. The second question is fully dependent on the settlement of the first one.

Most Chinese scholars insist that a country enjoys the power to decide on the jurisdictional competence of its courts over civil cases involving foreign elements unless otherwise prescribed by multilateral conventions or bilateral treaties to which the country is a party. ${ }^{40}$ In China, where a separate law of international civil procedure does not exist, the provisions on jurisdiction over domestic civil cases are as a rule also applied to civil cases involving foreign elements. ${ }^{41}$ In addition, China is a party to three Conventions which contain some provisions on jurisdiction over certain special kinds of international civil cases. ${ }^{42}$

\subsubsection{Jurisdiction of courts of a certain level}

According to the CPL, the basic people's courts exercise jurisdiction in first instance over civil cases involving foreign elements unless they are assigned by the law to the jurisdiction of higher level courts. Thus Article 19(1) of the CPL states that the intermediate people's courts exercise jurisdiction in first instance over 'important cases' involving foreign elements. Further, civil cases involving foreign elements, which exert an 'important influence' in the territory falling under the competence of higher Chinese people's courts or throughout the country, fall under the jurisdiction of the higher people's court concerned or, in the latter case, under the jurisdiction of the Supreme People's Court in first instance. ${ }^{43}$ In the 1992 'Opinions' of the Supreme People's Court the notion of 'important cases' refers to "foreign-related cases with a large-sum litigation object, or with complex case details, or with a great number of the parties residing abroad".

\footnotetext{
${ }^{39}$ See CAI FABANG, Zhongguo Minshi Susongfa [Chinese civil procedure law] (Beijing, 1992) 589.

${ }^{40}$ Ibid., p. 590.

${ }^{41}$ LI HAOPEI, op.cit. n. 4 p. 48.

${ }^{42}$ These are: the Convention on the Unification of Certain Rules on International Air Transportation, the International Agreement on Transport of Goods by Train, and the Convention on Civil Liability for Oil Pollution.

${ }^{43}$ CPL, Arts. 20 and 21.
} 


\subsubsection{Territorial jurisdiction}

Territorial jurisdiction or jurisdiction by region refers to the power of courts of the same level to entertain cases in first instance. Under the CPL, territorial jurisdiction can be further sub-divided into two categories: general territorial jurisdiction and special territorial jurisdiction. ${ }^{44}$

\subsubsection{General territorial jurisdiction}

In respect of general territorial jurisdiction, the maxim 'the plaintiff goes to the defendant' is regarded to be the basic principle. Article 22 of the CPL adheres to that principle and states:

"A civil lawsuit brought against a citizen shall be under the jurisdiction of the people's court of the place where the defendant has his domicile; if the place of the defendant's domicile is different from that of his habitual residence, the lawsuit shall be under the jurisdiction of the people's court of the place of his habitual residence.

A civil lawsuit brought against a legal person or any other organization shall be under the jurisdiction of the people's court of the place where the defendant has his domicile."

Consequently, the people's courts may exercise jurisdiction in civil cases involving foreign elements if the defendants' domicile or habitual residence is within Chinese territory.

Article 23 lays down 4 exceptions to the above principle. These exceptional cases fall under the jurisdiction of the people's court of the place of the plaintiff's domicile or habitual residence. One of these four exceptions is specifically related to international civil jurisdiction, i.e. lawsuits concerning personal status brought against persons not residing within the territory of the PRC. ${ }^{45}$

\subsubsection{Special Territorial Jurisdiction}

Special territorial jurisdiction is based on the object of the claim or the legal facts involved. According to Articles 23-33 of the CPL, the people's court can exercise jurisdiction over civil cases involving foreign elements if the defendant's domicile or habitual residence is not in Chinese territory whenever one of the following connecting factors refers to a place under the territorial jurisdiction of the court: (a) the place where the contract is to be performed $;^{46}$ (b)

\footnotetext{
${ }^{44}$ See CaI FABANG, Minshi Susong Faxue [Science of civil procedure law] (Beijing, 1991) 90.

${ }^{45}$ The other three exceptions are: lawsuits concerning the personal status of persons whose whereabouts are unknown or who have been declared as missing; lawsuits brought against persons who are undergoing rehabilitation through labour; and lawsuits brought against imprisoned persons. ${ }^{46} \mathrm{CPL}$, Art. 24.
} 
the place where the insured object is located $;^{47}$ (c) the place where the bill (of exchange) is to be paid, ${ }^{48}$ (d) the place of dispatch or destination (in disputes over transport contracts); ${ }^{49}$ (e) the place where the tort is committed; ${ }^{50}$ (f) the place where the accident has occurred or where the ship at fault is detained ${ }^{51}$ (g) the place where the salvage took place or where the salvaged ship first docked after the ship accident (in disputes concerning expenses of maritime salvage) $;{ }^{52}$ (h) the place where the salvaged ship first docked or where the adjustment of general average was conducted or where the voyage ended. ${ }^{53}$

Moreover, Article 243 of the CPL, also dealing with the jurisdiction of the court of the place of the performance of the contract, provides another six connecting factors by which the people's court can exercise jurisdiction over contractual or other disputes over property rights and interests in case of the defendant's domicile being outside China. These connecting factors are the place in China where the contract is signed or is to be performed, where the object of the action is located, where the defendant's distrainable property is located, where the tort is committed, and where the defendant's representative office is located. ${ }^{54}$

\subsubsection{Exclusive Jurisdiction}

In international civil procedure, exclusive jurisdiction refers to the fact that under the law of a state certain civil cases involving foreign elements are exclusively assigned to the jurisdiction of the courts of that country. Exclusive jurisdiction does not accept parallel jurisdiction, and cannot be avoided by agreement between the parties. ${ }^{55}$ Article 246 of the CPL specifically stipulates that the following three types of Sino-foreign contracts fall under the exclusive jurisdiction of the people's courts of the PRC: contracts on Sino-foreign contractual joint ventures, on Sino-foreign equity joint ventures and on Sino-foreign cooperative exploration and development of natural resources in the PRC which are performed in China. Article 34 of the CPL confers exclusive jurisdiction on people's courts at a certain place in case of certain types of actions in domestic civil procedure. It is suggested here that this provision may be equally applied in cases involving foreign elements. ${ }^{56}$ The actions and the respective courts are then as follows:

\footnotetext{
${ }^{47}$ Ibid., Art. 26.

${ }^{48}$ Ibid., Art. 27.

${ }^{49}$ Ibid., Art. 28.

${ }^{50}$ Ibid., Art. 29.

${ }^{51}$ Ibid., Arts. 30-31.

52 Ibid., Art. 32.

${ }^{53}$ Ibid., Art. 33.

${ }^{54}$ Ibid., Art. 243.

${ }^{55}$ See CAI FABANG, op.cit. n. 44 p. 101.

${ }^{56}$ See Jin PENGNIAN, op.cit. n. 4 p. 77.
} 
(a) An action arising from a dispute over real estate falls under the jurisdiction of the people's court at the place where the real estate is located; ${ }^{57}$

(b) An action lodged in connection with a dispute over the operations of a harbour falls exclusively under the jurisdiction of the people's court at the place of the harbour, ${ }^{58}$

(c) An action relating to a dispute concerning succession falls exclusively under the jurisdiction of the people's court at the place where the deceased had his domicile at the time of his death, or the place where the principal part of the estate is located. ${ }^{59}$

\subsection{The Exercise of Jurisdiction}

As mentioned above, the principle of 'the plaintiff goes to the defendant' also applies to jurisdiction in international civil cases. So if the defendant (a natural person or a legal person) has his domicile in China, the people's court has jurisdiction, with some exceptions. According to the General Provisions of Civil Law, ${ }^{60}$ the domicile of a natural person is the place where his residence is registered. If his habitual residence does not coincide with his domicile, his habitual residence is regarded as his domicile. ${ }^{61}$ The domicile of a legal person is the place where its main administrative office is located. ${ }^{62}$

If the defendant's domicile is not within the territory of the PRC, the CPL stipulates other connecting factors by which a people's court can exercise jurisdiction. Such a connecting factor, for example, is the fact that the place where the contract is performed, or where the tort is committed, or where the accident occurred, is in China. ${ }^{63}$

There are some special circumstances in which the people's court can exercise jurisdiction even if no effective connecting factors exist in China. Art. 126 of the CPL provides: "Additional claims by the plaintiff, counterclaims by the defendant and third-party claims related to the [original] case can be tried in combination". According to this article, the people's court is entitled to entertain these claims even if the general requirements for jurisdiction over each of the claims are not fulfilled. Some Chinese scholars, however, suggest that this article allows for some exceptions. For example, when the additional claims

\footnotetext{
${ }^{57}$ CPL, Art. 34(1).

58 Ibid., Art. 34(2).

${ }^{59}$ Ibid., Art. 34(3).

${ }^{60}$ The General Provisions of Civil Law (GPCL), which were adopted at the fourth session of the 6th NPC on 12 April 1986 and became effective as of 1 January 1987, consist of 156 Articles in 9 Chapters. Chapter 8 (Arts. 142-150) deals with the law applicable to civil relationships involving foreign elements.

${ }^{61}$ GPCL, Art. 15.

${ }^{62}$ Ibid., Art. 39.

${ }^{63}$ CPL, Arts. 24-34.
} 
concern real estate located abroad, it is obvious that the people's court may not try them in combination with the original one. ${ }^{64}$

The principle of perpetuatio fori is adhered to by both Chinese scholars and judicial practice. ${ }^{65}$ Although the CPL doesn't contain provisions to this extent, the Supreme People's Court has pointed out in its 1992 'Opinions' that once a people's court has started to entertain a case, its jurisdictional competency cannot be influenced by a change of a party's domicile or habitual residence. ${ }^{66}$

Finally, Article 245 of the CPL is particularly designed to confer jurisdiction over international civil cases to the people's court in case of non-fulfilment of the general requirements for such jurisdiction. ${ }^{67}$ It stipulates that a people's court may hear a suit over which it originally has no jurisdiction if the defendant raises no objection to its jurisdiction and responds to the action by making his defence. If these requirements are fulfilled, the defendant shall be deemed to have accepted the people's court's jurisdiction and is no longer able to raise objections. ${ }^{68}$

\subsection{Forum selection}

According to the CPL, the parties are entitled to opt for a court of their own choice. ${ }^{69}$ They may agree to submit their dispute to either a Chinese people's court or a foreign court. This freedom of choice is, however, limited by the

\footnotetext{
${ }^{64}$ Liu WeiXIANg, Yu Sulin, Zeng Ziwen and HuAng GuohUa, Zhongguo Guoji Sifa Lifa Lilun $Y u$ Shijian [Theory and Practice of the Legislation of Chinese Private International Law] (Wuhan, 1995) 225.

${ }^{65}$ LI SHUANGYUAN and XIE SHISONG, op.cit. n. 4 p. 191.

${ }^{66}$ See Art. 34 of the Opinions.

${ }^{67}$ Some scholars consider this article as a form of forum selection. In their opinion, forum selection consists of two types, i.e. in express form and in implied form, and Article 245 belongs to the latter type. See JIN PENGNIAN, op.cit. n. 4 p. 77.

${ }^{68}$ CAI FABANG, op.cit. n. 39 p. 598.

${ }^{69}$ The CPL contains two articles which regulate the question of forum selection. Art. 25 reads: "The parties to a contract may agree in their written contract on the choice of the people's court of the place where the defendant has his domicile, where the contract is performed, where the contract is signed, where the plaintiff has his domicile or where the object of the action is located, to exercise jurisdiction over the case, provided that the provisions of this Law regarding jurisdiction by forum level and exclusive jurisdiction are not violated". Art. 244 reads: "Parties to a dispute over a contract with a foreign element or over property rights and interests involving foreign elements may, through written agreement, choose the court of the place which has practical connections with the dispute to exercise jurisdiction. If a people's court of the PRC is so chosen to exercise jurisdiction, the provisions of this Law on jurisdiction by forum level and on exclusive jurisdiction shall not be violated".

These two articles have both similarities and differences. Art. 25 is limits to a situation of contract, while Art. 244 covers disputes arising from contract as well as from property rights and interests. Chinese scholars differ as to the relationship between these two Articles. Some hold that Art. 25 applies only to domestic civil cases while Art. 244 applies to civil cases involving foreign elements. Others insist that Art. 25 can also be applied to foreign-related cases.
} 
following requirements: ${ }^{70}$ (a) only parties to a dispute over a contract with a foreign element or over property rights and interests involving a foreign element have the right to choose; (b) the parties' choice should be made in written form; (c) the court chosen by the parties must have practical connections with the dispute; (d) if the choice is made in favour of a people's court of the PRC, the provisions of the CPL on forum level and on exclusive jurisdiction shall in any case be applicable. The CPL sets a further limit to the parties' freedom to choose a forum by conferring exclusive jurisdiction on the people's courts of the PRC over actions concerning the performance of contracts on Sino-foreign equity joint ventures, Sino-foreign contractual joint ventures, and Sino-foreign cooperative exploration and development of the natural resources in the PRC. ${ }^{71}$

As to other issues relating to forum selection, such as the law applicable to the determination of the validity of the selection and the question whether and to what extent the parties may derogate from the selection made, we can hardly find answers in present Chinese law. Many Chinese scholars favour the application of the lex fori for the determination of the validity of the selection.

\subsection{Lis pendens}

Lis pendens has not received adequate attention among Chinese scholars, nor in Chinese legislation. ${ }^{72}$ The CPL devotes only one Article to the question of lis pendens which applies exclusively to domestic cases. ${ }^{73}$ According to this Article, parallel proceedings are not allowed. With regard to international civil and commercial cases, however, the attitude of the people's courts towards parallel proceedings is quite different. This conclusion can be drawn from Articles 15 and 306 of the 1992 'Opinions' of the Supreme People's Court which read, respectively:

"In a divorce case where one party files a lawsuit in a foreign court and the other party resorts to a Chinese court, the Chinese people's court will entertain the case."

and:

"The people's court may exercise jurisdiction over a case which falls under the jurisdiction of both the people's court of the PRC and a foreign court if one

\footnotetext{
${ }^{70}$ See CaI Fabang, op.cit. n. 44 p. 101.

${ }^{11} \mathrm{CPL}$, Art. 246.

${ }^{72}$ There is only one article published in China on this issue: ZHANG MAO, 'Guoji Minshi Susong Zhongde Susong Jinhe' [Parallel proceedings in international civil litigation], Faxue Yanjiu [Journal of Law] no. 18 (Chinese Academy of Social Sciences, 1996).

${ }^{73}$ Art. 35 of the CPL: "When two or more people's courts have jurisdiction over a lawsuit, the plaintiff may bring his lawsuit in one of these; if the plaintiff brings the lawsuit in two or more people's courts that have jurisdiction over the lawsuit, the people's court in which the case was first entertained shall exercise jurisdiction". This article is silent on the situation arising if one party brings the lawsuit in one competent people's court, while the other party brings the lawsuit in another competent court, and on how then to determine the court that shall exercise jurisdiction.
} 
party has submitted the case to a foreign court. When the foreign court has rendered a judgment in the case and an application is filed to a people's court for recognition and enforcement, the people's court shall reject the application unless otherwise stipulated by the treaties to which China and the country concerned are parties."

It is obvious that these regulations are very vague and do not tally with the practice adopted by many other countries. ${ }^{74}$

Some bilateral treaties concluded by China on judicial assistance contain provisions on lis pendens, but they are inconsistent. ${ }^{75}$ Most of the bilateral treaties provide that the requested country will not recognize or enforce a judgment rendered by the court of a requesting country if the same case is being handled by the court of the requested country, regardless of which court entertained the case first. Some other bilateral treaties stipulate that the requested country may not refuse to recognize and execute a foreign judgment unless its court has taken cognizance of an identical case before the foreign court had done so. ${ }^{76}$

\subsection{Immunities}

The Huguang Railway Bonds case ${ }^{77}$ brought about a comprehensive discussion on the question of immunities in China in the 1980 s. $^{78}$ Almost all Chinese

\footnotetext{
${ }^{74}$ See ZHANG MAO, loc.cit. n. 72.

${ }^{75}$ See Li Shuangyuan, Jin Pengnian, Zhang Mao and Li ZhiYong, Zhongguo Guoji Sifa Tonglun [A general introduction to Chinese private international law] (Beijing, 1996) 580.

${ }^{76}$ See Art. 18(4) of the agreement with Mongolia, and Art. 21(5) of the agreement with Italy, in FeI ZoNGyi and TANg ChEnYUAN, Zhongguo Sifa Xiezhu de Lilun Yu Shijian [Theory and Practice of Judicial Assistance in China] (Beijing, 1992) 267 and 303.

${ }^{77}$ In November 1979 some Americans initiated lawsuits in the US against the Chinese government claiming the repayment of bonds issued on the occasion of the building of the Huguang Railway by the Qing imperial government in 1911. On 9 March 1987 the US Supreme Court rejected the claims.

${ }^{78}$ Almost all Chinese general treatises on private international law contain a chapter on the matter of immunities. In addition, there are some articles and two monographs especially devoted to the issue. The articles include: SUN LIN and SUN HONGHONG, 'Guoji Zuzhi de Tequan yu Huomian' [Privileges and immunities of international organizations], Chinese Yearbook of International Law (1982); Chen TIQIANG, 'Guojia Zhuquan Huomian yu Guojifa-Ping Huguang Tielu Zhaijuanan' [Immunity of sovereignty of state and international law: on the Huguang Railway Bonds Case], ibid.; LI ZHERUI, 'Guojia Huomian Wenti de Huigu yu Qianzhan' [State immunity: its history and future], Chinese Yearbook of International Law (1986); LI HAOPEI, 'Lun Guojia Guangxia Huomian' [On jurisdictional immunity of a state], ibid.; HUANG JIN, 'Lun Xianzhi Guojia Huomian Lilun' [On the theories of restrictive immunity of states], ibid.; Jiang Zhaodong, 'Waiguo Guojia Huomian Guize yu Youguan Guoji Shangshi Zhongcai de Susong' [Rules of foreign state immunity and relevant questions of immunity and international commercial arbitration], Chinese Yearbook of International Law (1987); LI SHUANGYUAN, 'Meiguo 1976 nian Waiguo Zhuquan Huomian Fa suo Fengxing de Xianzhi Huomian Lun Pipan' [Critique on the theory of restrictive immunity adopted in the American Act on Sovereign Immunity of Foreign States of 1976] Faxue Pinglun [Law Review] (Wuhan, no. 1, 1983). The two monographs are HUANG JIN, Guojia Jiqi Caichan
} 
scholars support the principle of 'absolute sovereign immunity' and criticize the practice of 'restrictive immunity' adopted by some developed countries. ${ }^{79}$ They maintain that immunities can be divided into two categories, state immunity and diplomatic immunity, ${ }^{80}$ and that the following three aspects may be distinguished: immunity from judicial jurisdiction, immunity from litigation procedures (such as giving evidence) and immunity from compulsory execution.

The provisions on the immunities of states and their property are scattered among the following laws: the CPL ${ }^{81}$ the PRC Regulations on Diplomatic Privileges and Immunities, and the PRC Regulations on Consular Privilege and Immunities. In addition, China is a party to some treaties containing special provisions on immunities. ${ }^{82}$

The Chinese principles on immunities, which have been developed through Chinese legal and diplomatic practice and elaborated by Chinese scholars, can be summarized in the following points:

A. China views the immunity of states, and their property, from the jurisdiction of courts of other countries as a natural right of sovereign states, and also as a principle of international law. The PRC favours the doctrine of absolute sovereign immunity and opposes the doctrine of restrictive immunities or the abolition altogether of immunities.

B. A distinction must be made between the state's own activities and property and the activities and property of state corporations and enterprises. While China adheres to absolute sovereign immunity, it does not seek immunity for the activities and property of its state corporations. "China holds that state corporations and enterprises are separate economic entities with their own independent legal status, so they should not enjoy sovereign immunity." 83

C. Immunity of diplomatic agents from the civil and administrative jurisdiction of Chinese people's courts, with some exceptions, is laid down as a principle in Chinese law.

D. The principle of reciprocity is to be applied by Chinese courts vis-à-vis those countries which restrict the immunity of China and its state property in contravention of international law.

\footnotetext{
Huomian Wenti Yanjiu [A Study of the Immunity of States and their Property] (Beijing, 1987); GoNG RenRen, Guoji Huomian Wenti Bijiao Yanjiu [A Comparative Study of the Question of International Immunities] (Beijing, 1994).

${ }^{79}$ A few Chinese scholars neither approve the doctrine of absolute immunity, nor support the doctrine of restrictive immunity. In their view, the enjoyment of judicial immunity in international civil litigation by states and their property is a basic principle of international law. See LI SHUANGYUAN and XIE SHISONG, Guoji Minshi Susongfa Gailun [An Introduction to the Law on International Civil Procedure] 280.

${ }^{80}$ See Li ShuAngyuan (ed.), Guoji Sifa [Private International Law] (Beijing, 1991) 458.

${ }^{81}$ CPL, Art. 239.

${ }^{82}$ Such as the Vienna Convention on Diplomatic Relations, the Vienna Convention on Consular Relations and the Convention on the Privileges and Immunities of the United Nations.

${ }^{83}$ See Li SHUANGYUAN and XIE SHISONG, op.cit. n. 4 p. 279.
} 
E. Jurisdictional immunity enjoyed by sovereign states, diplomatic agents, and international organizations, can be waived by the states and the international organizations concerned. ${ }^{84}$

\section{SERVICE OF PROCESS}

\subsection{Means}

The service of documents abroad refers to the service of judicial and extrajudicial documents to parties or other litigants residing abroad, according to international treaties, national law or the principle of mutual benefit ${ }^{85}$ It may refer to service of Chinese documents outside China as well as service of documents from abroad on parties in China.

\subsubsection{In case of absence of treaties}

According to Article 247 of the CPL, a people's court may serve litigation documents on a party who doesn't have domicile in China by one of the following means if there are no treaty provisions applying to China and the country where the party to be served resides:

\section{A. Diplomatic Channels}

Diplomatic channels are the most important means recognized and adopted by China and other countries to serve documents abroad. ${ }^{86}$ On 14 August 1986, the Supreme People's Court, the Ministry of Foreign Affairs and the Ministry of Justice jointly issued a Notice on Certain Matters Relating to the Service of Legal Documents through Diplomatic Channels between the People's Courts and Foreign Courts. This Notice bases the service by diplomatic channels on the principle of mutual benefit and lays down the procedure which the people's courts and foreign courts should observe in serving civil and economic judicial documents.

\section{B. By entrustment}

Service outside China may be entrusted to the embassy or consulate of the PRC accredited to the country where the person resides if the person is of Chinese nationality ${ }^{87}$ Similarly, foreign embassies and consulates in China may serve legal documents directly on their nationals in China provided that such

\footnotetext{
${ }^{84}$ See Art. 15, PRC Regulations on Diplomatic Privileges and Immunities.

${ }^{85}$ JiNG PENGNIAN, op.cit. n. 4 p. 109.

${ }^{86}$ CPL, Art. 247(2).

${ }^{87}$ CPL, Art. 247(3).
} 
documents are not detrimental to the sovereignty or security of China and no coercive measures are applied. ${ }^{88}$

C. Service may be executed on the agent ad litem who is authorized to receive the documents served. ${ }^{89}$

D. The documents may be served on the representative who has been entrusted by the litigant to receive service of documents. ${ }^{90}$

E. Documents may be served by mail where the law of the country in which the litigant to be served has his abode, permits such service. If the documents are mailed and no certificate of delivery has been received within six months, service will nonetheless be regarded as having been made if it can otherwise be confirmed - taking account of all the circumstances - that the service has been carried out.

F. When a document cannot be served through the above-mentioned means, it must be served by public notice. It is deemed to be served after six months from the date of such notice.

The CPL strictly prohibits the service of legal documents within the jurisdiction of the PRC by foreign organizations or persons, unless expressly approved by the appropriate Chinese authorities. ${ }^{91}$ Hence, in the absence of relevant treaty provisions, diplomatic channels remain the chief method for the service of documents abroad.

\subsubsection{Under bilateral treaties}

As mentioned earlier, ${ }^{92}$ China has concluded bilateral treaties with 19 countries on civil and commercial judicial assistance, in which the service abroad of judicial and extrajudicial documents is regulated. On 1 February 1988, the Supreme People's Court issued a Notice on the implementation of Sino-foreign judicial assistance agreements designating the Ministry of Justice as the central authority to accept and send out the application papers and the judicial documents to be served. When the Ministry receives judicial documents to be served in China from the other party to the treaty, it shall transmit them to the Supreme People's Court for conveyance to a higher people's court for further disposal of the matter. The latter assigns the execution of the service

\footnotetext{
${ }^{88}$ Art. 2 of the above-mentioned Joint Circular from the Supreme People's Court, the Ministry of Foreign Affairs and the Ministry of Justice of 1986.

${ }^{89}$ CPL, Art. 247(4).

${ }^{90} \mathrm{CPL}$, Art. 24(5).

${ }^{91}$ CPL, Art. 263(3).

${ }^{92}$ Supra n. 33.
} 
to an intermediate people's court or a special court in accordance with the regulations laid down in the bilateral agreement.

\subsubsection{Under the 1965 Hague Service Convention}

As the first and only Convention of the Hague Conference on Private International Law that has been ratified by the PRC, the 1965 Hague Service Convention is given much emphasis by Chinese authorities and scholars because its provisions basically tally with the spirit of relevant Chinese laws and judicial practice. In ratifying the Convention, China made a reservation to Article 8(1) and to Article $10 .{ }^{93}$ According to this reservation, service by diplomatic or consular agents can only take place within PRC territory when the documents are served upon a national of the state where the documents have originated. Furthermore, under Article 10 of the Convention, the PRC has opted for objecting to, and thus not allowing, the three liberal means of service offered in that Article.

In order to better implement the Convention in China, the Supreme People's Court, the Ministry of Foreign Affairs, and the Ministry of Justice jointly issued two circulars (supra p.143). The Circulars designated the Ministry of Justice as the central authority in China to receive documents served by consular channels, and specified the concrete procedures on the service of documents from China to foreign countries and from foreign countries to China.

\subsection{Procedures}

Procedures for service abroad are largely determined by the means of service. In some circumstances, the procedures are very simple, such as service by mail, service by public notice, service made on the agent ad litem or the

\footnotetext{
${ }^{93}$ In ratifying the Convention, the Standing Committee made the following declarations:

(1) In accordance with the provisions of Article 2 and Article 9 of the Convention, the Ministry of Justice of the People's Republic of China is designated as the Central Authority that is also entitled to receive the documents forwarded through consular channels.

(2) It is declared, in accordance with paragraph 2 of Article 8 of the Convention, that the method of service regulated in the first paragraph of this Article can only be used within the territory of the People's Republic of China when a document is to be served upon a national of the state from which the documents originate.

(3) It is not permitted to use the methods of service provided for by Article 10 of the Convention for service within the territory of the People's Republic of China.

(4) It is declared, in accordance with paragraph 2 of Article 15 of the Convention, that a judge, notwithstanding the provisions of the first paragraph of this Article, may render judgment even if no certificate of service or delivery is received if all the conditions provided for by paragraph 2 of this Article are fulfilled.

(5) It is declared, in accordance with paragraph 3 of Article 16 of the Convention, that a defendant may apply for relief from losing the right to appeal for not having taken recourse to it within a year from the date of the judgment.
} 
representative office, etc. At present, documents are served mainly through diplomatic channels in China, and our discussion here consequently focuses on the procedures for service through diplomatic channels. The procedures specified in the 1965 Hague Service Convention and the bilateral agreements will be referred to briefly.

According to the 1986 Notice on the service of legal documents through diplomatic channels, the following procedures shall be followed in case of service of legal documents upon a natural person or a legal person with the nationality of the PRC or of a third country on behalf of a foreign court:

(a) The documents must be delivered to the Consular Section of the Ministry of Foreign Affairs of the PRC by the embassy or consulate of the country in question. The Consular Section transmits the documents to the relevant higher people's court, which designates the relevant intermediate people's court to serve the documents upon the party concerned. Depending on whether or not the party served has signed a certificate acknowledging receipt of service, the intermediate people's court returns this certificate or the attestation of service to the authorizing party through the Consular Section of the Ministry of Foreign Affairs.

(b) A letter of authorization must be issued for the service. All such letters and accompanying legal documents must be served together with Chinese translations attached thereto.

(c) Legal documents containing detrimental statements relating to the sovereignty or security of China will be rejected; when the person towards whom the service must be performed enjoys diplomatic privileges or immunities, the document is as a rule not accepted for service. When service does not take place for being outside the jurisdiction of the Chinese courts, or because it is unclear for whom the document is intended, or for any other reason, the relevant higher people's court must state how the matter should be handled further and clearly state the reasons for the non-execution of the service. The Consular Section of the Ministry of Foreign Affairs will be responsible for returning the document to the authorizing party with an appended explanation.

The 1986 Notice also stipulates the procedures and requirements which the people's court must observe in case of the reverse service of legal documents upon a party outside the territory of China through diplomatic channels:

(a) The legal documents to be delivered abroad shall first be approved by the higher people's court of the province, autonomous region or municipality (from where the request originated) and then transmitted (to the requested country) by the Consular Section of the Ministry of Foreign Affairs.

(b) The correct name, sex, age, nationality and address abroad of the intended recipient shall be provided, together with the document to be delivered. The material facts of the case shall be disclosed to the Consular Section of the Ministry of Foreign Affairs.

(c) A letter of authorization must be attached to the documents. If the name of the foreign court is not known, the request shall be addressed to the higher court of the jurisdiction in which the foreign party resides. A translation of the 
authorization letter and the documents into the language of the requested country or, with the consent of that country, into another language, shall also be attached. If the requested country requires the legal documents to be legalized or authenticated, the Consular Section of the Ministry of Foreign Affairs shall so notify the requesting people's court. ${ }^{94}$

The methods of service of documents as regulated in China's judicial assistance agreements and the 1965 Hague Convention are to a high degree similar. The authorization letter requesting the service of judicial and extrajudicial documents must be submitted by the requesting state's central authority, or consulate in the case of the Hague Service Convention, ${ }^{95}$ to that of the requested country. The form of the authorization letter and the language to be used are stipulated in the appendices of the treaties. Typically, the authorization letter must be written in the official language of the requesting party and accompanied by a translation in the counterpart's language. ${ }^{96}$

Since the treaties do not prescribe detailed procedures for the effectuation of the service, the central authority of the requested party chooses the appropriate methods according to its domestic law. ${ }^{97}$ If, however, the address of the person on whom a document is to be served is unclear or incomplete, the requested central authority may ask for further information. If the address remains unclear and the document cannot be served, the central authority should notify its counterpart and return all documents.

A receipt is required for every document served and must bear the addressee's signature and the date of receipt. Moreover, the central authority must record the method of service, the place and the date on the receipt. A request for judicial assistance, including the service of documents, may be refused if the request is contrary to the sovereignty, national security, or ordre public of the requested state. The requested state is, however, obliged to provide the requesting country with an explanation for the refusal.

\footnotetext{
${ }^{94}$ According to Art. 7 of the Notice on the implementation of the 1965 Hague Convention, a bilateral agreement concluded with another state party of the 1965 Hague Convention shall have priority in case of inconsistency with the Convention.

${ }_{95}^{95}$ Hague Service Convention, Art. 9.

${ }^{96}$ For example, Art. 6 of the Sino-French Treaty stipulates that all judicial and extrajudicial documents shall include a copy and a translation in the counterpart's language. Arts. 8 and 8(1) of the Sino-Polish and Sino-Mongolian treaties, respectively, stipulate that judicial assistance applications should include either a translation in the language of the requested country or in English.

${ }^{97}$ See French-Sino Treaty, Art. 7; Sino-Mongolian Treaty, Art. 10.
} 


\section{TAKING OF EVIDENCE ABROAD}

\subsection{Means}

The system of evidence-taking in China is quite different from that in common law countries as well as that in civil law countries. ${ }^{98}$ This gives rise to serious conflicts of laws between China and other countries. As to the taking of evidence abroad, regulation in China is quite undeveloped and remains, for the time being, dependent on domestic laws. Similar to service of process abroad discussed above, the means that may be used for the taking of evidence abroad, as stipulated by Article 262 of the CPL, may be conveniently sub-divided into two categories: direct and indirect means. The provision reads:

"In accordance with the international treaties concluded or acceded to by the PRC, or the principle of reciprocity, a people's court and its foreign counterpart may request each other to assist in the service of legal documents, in carrying out investigation, in collecting evidence, or in other actions regarding litigation."

A people's court shall not handle a request from a foreign court, if the case in question undermines the PRC'S sovereignty, security or social and public interests.

\subsubsection{In case of absence of treaties}

Under Article 263 of the CPL, when no regulation by treaty exists, the taking of evidence abroad is permitted through diplomatic channels on the basis of the principle of reciprocity. The above-mentioned Notice of 1986 jointly issued by the Supreme People's Court and the Ministries of Foreign Affairs and Justice prescribes in its Article 8 that "[i]n rendering mutual assistance in the taking of evidence between our courts and foreign courts, the above procedures [on judicial assistance through diplomatic channels] may be applied by analogy". Thus the Notice also covers the taking of evidence abroad. According to the law and the joint Notice, except for a foreign embassy or consulate, no foreign organization or individual may, without the consent of the competent authorities of the PRC, serve documents or make investigations and collect evidence within the territory of the PRC. Moreover, the CPL places the following limits on the taking of evidence by consuls: (a) the person to be investigated must have the nationality of the home state of the embassy or consulate; (b) the laws of the PRC must not be violated; (c) no compulsory measures may be taken. ${ }^{99}$

\footnotetext{
${ }^{98}$ See Jing PENGNIAN, op.cit. n. 4 pp. 126-128.

${ }^{99}$ CPL, Art. 263(2).
} 


\subsubsection{Under bilateral agreements}

Although China has not participated in multilateral conventions on the taking of evidence abroad, almost all the Chinese bilateral agreements on judicial assistance include some articles on this issue. ${ }^{100}$ Besides, as the circumstances of service of documents abroad resemble those of the taking of evidence abroad in many respects, quite a few provisions relating to the former may be applied to the latter and vice versa.

In most of the agreements, the taking of evidence abroad includes more or less the following items: ${ }^{101}$

(a) The scope of evidence-taking, comprising the examination of the parties, the witnesses, and the identifier, carrying out inspection and judicial certification, and collecting other evidence;

(b) The form of the letter of request, which is often appended to the agreement;

(c) The law applicable to the taking of evidence abroad. The majority of the agreements adhere to the lex fori as the applicable law;

(d) The regulation of the protection of witnesses and identifiers;

(e) The supply of documents on civil commercial substantive law, law of procedure and judicial practice.

Apart from bilateral assistance agreements, China has concluded or acceded to some consular treaties which contain a few provisions on the taking of evidence abroad, but these provisions are usually limited and vague.

On 18 March 1970, the Hague Conference on Private International Law adopted a comprehensive Convention on the Taking of Evidence Abroad in Civil or Commercial Matters. Although China is not a party to the Convention, it is obvious that many provisions of the Convention are basically consistent with the stipulations in China's judicial assistance agreements, and the Convention is sure to have exerted much influence on China's practice in the domain of evidence-taking abroad. ${ }^{102}$

\subsection{Procedures}

As the taking of evidence abroad is, for the time being, mainly carried out by means of a letter of request in China, ${ }^{103}$ we shall limit ourselves here to the procedures followed in employing this means. First, a letter of request shall be sent to the central authority of the state of execution in light of the procedures and requirements stipulated by the domestic law of that state or by international

\footnotetext{
${ }^{100}$ Some bilateral agreements separate the provisions on service from the provisions on evidence taking. Others combine and mix these provisions.

${ }^{101}$ See LI HAOPEI, op.cit. n. 4 pp. 195-197.

${ }^{102}$ See JiNg PENGNIAN, op.cit. n. 4 p. 129.

${ }^{103}$ Ibid.
} 
treaties. ${ }^{104}$ The letter of request must be in specified form and must have the required contents. ${ }^{105}$ Furthermore, it must be made in the language of the state of execution or be accompanied by a translated version. ${ }^{106}$

After receiving the letter of request, the requested authority shall, according to its domestic law, collect the evidence. Where the letter of request requires special methods or procedures, the requested authority shall follow them unless they are in conflict with his domestic law. ${ }^{107}$ In China, after receiving the letter of request, the Ministry of Justice shall transmit it to the Supreme People's Court which then sends it to an appointed intermediate people's court through a higher people's court. Generally speaking, it is the intermediate people's courts or special courts that undertake the responsibility for collecting evidence.

After having collected the evidence, the requested authority shall inform the requesting authority and transmit the evidence materials to it. If the requested authority has been unable to collect the evidence for various reasons, it must inform the requesting authority accordingly. Under Chinese law, the people's court shall not collect the evidence requested by a foreign authority if it impairs the sovereignty, security, or social and public interest of the PRC. ${ }^{108}$

\section{RECOGNITION AND EXECUTION OF FOREIGN JUDGMENTS ${ }^{109}$}

\subsection{Essence and place}

Scholarly doctrine and the current legislation in China differ with regard to the relation between recognition and execution of foreign judgments and judicial assistance. Recognition and execution of foreign judgments is defined by many Chinese scholars as a subject separate from judicial assistance. ${ }^{110}$ But the Chinese bilateral agreements on civil and commercial judicial assistance cover also the recognition and enforcement of foreign judgments and arbitral awards. For the sake of convenience the present paper follows the scholars' view and deals with the subject of recognition and execution of foreign judgments separately from judicial assistance. ${ }^{111}$

\footnotetext{
${ }^{104}$ Under Art. 2 of the 1970 Hague Convention, the Central Authority to receive letters of request coming from abroad and to transmit them to the authority competent to execute them is designated by the state itself. In China, the Ministry of Justice is designated as the Central Authority.

${ }^{105}$ Art. 3 of the 1970 Hague Convention lists 9 items altogether. See JiNG PENGNIAN, op.cit. n. 4 p. 129.

${ }^{106}$ CPL, Art. 264(2).

${ }^{107}$ Ibid., Art. 265.

${ }^{108}$ Ibid., Art. 262(2).

109 "Foreign judgment" should be understood in a broad sense, comprising judgments rendered by foreign courts as well as written orders, mediation statements, etc.

${ }^{110}$ See Li ShuAngyuan, Guoji Sifa [Private International Law] (Beijing, 1991) 469.

${ }^{111}$ In the broad sense of the term, judicial assistance should include the recognition and execution of foreign judgments and arbitral awards.
} 
Generally speaking, to recognize foreign judgments is to endow the foreign judgment with the same legal effect as that of a domestic judgment. To enforce foreign judgments is to force the parties to fulfil their obligations provided by the foreign judgment. The recognition of a foreign judgment is a prerequisite for the enforcement of that judgment. ${ }^{112}$ Of course, the recognition of foreign judgments doesn't necessarily lead to their enforcement, if only because some foreign judgments, such as those on the capacity of a person and divorce, only require recognition and do not need to be executed.

In certain countries, foreign judgments need no explicit recognition and are automatically effective, but under Chinese law and the treaties concluded by China, we cannot find an answer to this question. In 1991, the Supreme People's Court issued a circular concerning the procedures to be followed by Chinese citizens in applying for the recognition of foreign divorce judgments. Article 20 of this circular points out that, as long as a party has not applied to the people's court for the recognition of a foreign judgment in a matrimonial dispute, the other party retains the right to bring a new divorce action before a people's court. Based on this Article, many Chinese authors have come to the conclusion that the legal effect of foreign judgments in China is not automatic and that such judgments must be recognized by a Chinese people's court in order to have legal effect in the Chinese legal order. ${ }^{113}$

\subsection{The legal basis of recognition and execution of foreign judgments}

International conventions and mutual benefit are the two legal bases for the recognition and execution of foreign judgments. ${ }^{114}$ Article 267 of the CPL stipulates that a foreign court may, in accordance with the provisions of treaties to which the foreign country involved and China are bound, or on the basis of the principle of reciprocity, request for recognition and enforcement of its judgment by a people's court. Article 268 further prescribes that, in examining the application, the people's court follow the treaties concerned and the principle of reciprocity.

As to the principle of mutual benefit, we can hardly find any specific definition of this concept in Chinese law or legal practice. It has met with strong opposition and criticism for its vagueness. Some Chinese scholars even assert that recognition and execution of foreign judgments based on mutual benefit is neither reasonable nor practicable. ${ }^{15}$

\footnotetext{
${ }^{112}$ LI SHUANGYUAN, op.cit. n. 110, p. 486.

${ }^{113}$ See Jing PENGNIAN, op.cit. n. 4, p. 138.

${ }^{114}$ See FEI ZONGYI and TANG CHENYUAN, op.cit. n. 76 p. 118.

115 LI HAOPEI, one of the most senior Chinese legal scholars, pointed out that the principle of benefit is in fact a principle of reprisal. See LI HAOPEI, op.cit. n. 4 pp. 140-141.
} 


\subsection{Requirements}

Article 268 of the CPL lays down two main requirements which foreign judgments must fulfil in order to qualify for recognition and enforcement: they must be final and they may not contradict the basic principles of the law of the PRC nor violate the sovereignty, security and social and public interest of China. Besides these requirements, Chinese authors have listed some others, including the following: ${ }^{116}$ (a) the foreign court which rendered the judgment had jurisdiction over the case; (b) the litigation in the foreign court was fair; (c) the foreign judgment was not in conflict with a domestic judgment between the same parties on the same dispute, nor inconsistent with a judgment rendered by a third country and recognized by a Chinese court, between the same parties on the same dispute; (d) the recognition and enforcement was allowed under treaties in force between China and the requesting State, or there existed a 'mutually beneficial relationship' between the two countries; (e) the judgment has applied the proper lex causae.

\subsection{Procedure}

According to Article 266(1) of the CPL, a litigant may directly apply to a competent foreign court for recognition and enforcement of a legally binding judgment rendered by a Chinese court. A people's court itself may also request a foreign court to recognize and enforce one of its judgments. Such a request may be made at the instigation of the victorious litigant, either under the provisions of an international treaty or on the basis of the principle of reciprocity, whenever the convicted party or his property is not within Chinese territory.

Reversely, the CPL also provides that a foreign litigant may directly apply to a Chinese people's court for the recognition and enforcement of a foreign judgment. ${ }^{117}$ Similarly, the foreign court may make such a request, either under a treaty binding its home state and the PRC or on the basis of the principle of reciprocity or mutual benefit. ${ }^{118}$

Generally speaking, the procedure followed for the recognition and enforcement of foreign judgments by a Chinese people's court can be roughly divided into the following three stages:

(1) the application - as mentioned above, the application may come either from the litigant or from the foreign court. In both cases some necessary papers have to be presented to the people's court, such as a verified copy of the judgment, a Chinese version of it, etc.

(2) the examination - upon receipt the people's court examines the application to see whether it meets the requirements. In accordance with the CPL and the

\footnotetext{
${ }^{116}$ See Jing PENGNIAN, op.cit. n. 4 pp. 142-148.

${ }^{117}$ CPL, Art. 267.

${ }^{118}$ Ibid.
} 
judicial assistance agreements to which China is a party, Chinese courts have adopted the system of examination on form rather than examination on substance. For example, Article 18(2) of the Judicial Assistance Convention between the PRC and the Russian Federation stipulates clearly that the requested court may limit itself to examining whether the judgment is in conformity with the provisions of the Convention, without an examination on substance.

(3) The last stage is the recognition and enforcement itself. After examination, the foreign judgment may be recognized and enforced by the Chinese people's court unless it is found to be in contravention with the basic principles of the law or with the sovereignty, security, and social and public interests of the PRC, or if it does not meet other necessary requirements. ${ }^{119}$ For the enforcement of a foreign judgment in China, an enforcement decree is issued by the people's court. The judgment will be enforced in accordance with the relevant provisions and rulings on the execution of domestic judgments. ${ }^{120}$

\section{ARBITRATION}

\subsection{The position of arbitration}

Arbitration is becoming ever more important in China as a means for the resolution of both domestic and international civil and commercial disputes. On 31 August 1994 a Chinese arbitration law was adopted at the ninth session of the Standing Committee of the Eighth NPC. It entered into force on 1 September 1995. The law consists of eight chapters and 80 articles. Chapter Four, on "Special provisions on arbitration involving foreign elements", lays down the fundamental provisions on international civil and commercial arbitration. At present, there are two arbitration institutions dealing with international civil commercial and maritime disputes in China, namely the International Economic and Trade Arbitration Commission and the Maritime Arbitration Commission. Both have their own regulations and are gaining a favourable reputation for their fairness and promptness. ${ }^{121}$

According to the Arbitration Law and the two regulations, arbitration may take place on the basis of an arbitration clause in the contract or an arbitration agreement between the parties. A lawful arbitration clause or arbitration agreement can exclude the jurisdiction of the courts in favour of the will of the parties. They may submit their disputes to an arbitral tribunal in the home

\footnotetext{
119 See supra.

${ }^{120}$ Arts. 207-236 of the CPL provide for the execution of domestic judgments and rulings. They can also be applied to the execution of foreign judgments.

${ }^{121}$ See JiNG PENGNIAN, op.cit. n. 4 pp. 196-203. On 17 March 1994, the Chinese International Commercial Commission (or Chinese International Trade Promotion Commission) amended its "Arbitration Rules of the Chinese International Economic Trade Arbitration Commission". The new Rules came into force on 1 June 1994.
} 
country of any of the parties or in a third country. The arbitrators, the arbitration rules and the applicable law can also be chosen by the parties. The award rendered by a Chinese arbitral institution is final and binding, and the parties can no more file a suit concerning the same dispute in any Chinese court. If, however, a party refuses to perform its obligations under the arbitral award, ${ }^{122}$ the other party may file an enforcement action in court.

\subsection{The power of the court to examine the validity of arbitration awards}

Generally speaking, the parties enjoy the right either to submit their disputes to arbitration or to the court. Their choice depends, inter alia, on whether or not they have arrived at an arbitration agreement or have included an arbitration clause in their contract. If they have done so, only the arbitral tribunal is competent to handle the dispute. Since arbitral institutions have no right to enforce their own awards, the court has the power to determine the validity of arbitral awards. Article 260 of the CPL stipulates that a people's court shall refuse to recognize the validity of an arbitral award and shall not enforce it if it is proven that: (a) the parties have in fact not agreed to an arbitration clause in the contract or have not subsequently reached a written arbitration agreement; or (b) the party against whom the enforcement is intended has not been given notice of the appointment of an arbitrator or of the inception of the arbitration proceedings, or was unable to present his case due to causes for which he is not responsible; or (c) the composition of the arbitration tribunal or the arbitration procedure was not in conformity with the rules of arbitration; or (d) the issues dealt with by the award fall outside the scope of the arbitration agreement or are matters which the arbitral organ was not empowered to arbitrate. ${ }^{123}$ The people's court shall also ignore the legal effects of an arbitral award if it determines that the enforcement of the award would go against the social and public interests of the PRC.

\section{MEDIATION}

Mediation has for centuries been the most favoured dispute resolution technique among Chinese. At present it is still regarded as a useful mode of dispute settlement. According to the CPL, mediation includes two categories: mediation in litigation and mediation out of court. The main difference between the two is that the former is legally binding upon the parties, while the latter doesn't have any legal effect.

\footnotetext{
${ }^{122}$ Arbitration Law, Art. 62.

${ }^{123}$ CPL, Art. 260.
} 


\subsection{Mediation in litigation}

Mediation in litigation, also called mediation by court, is a basic and important method that can be carried out at any stage of the litigation, ${ }^{124}$ including the procedures of first or second instance and that of trial supervision. ${ }^{125}$ It is, however, clearly specified in the CPL that mediation relies on the parties' consent and that the courts cannot force the parties to settle their dispute by mediation against their will. Article 9 of the CPL stipulates that the people's courts, in trying civil cases, shall conduct mediation for the parties on a voluntary and lawful basis. If mediation fails, judgment shall be rendered without delay.

In most cases, when a settlement agreement is reached through mediation, the people's court draws up a mediation statement. The mediation statement is quite similar to a judgment as far as the contents are concerned. It must clearly set forth the facts of the case, the claims, and the result of the mediation. It shall, moreover, be signed by the judge and the court clerk, and appended with the seal of the people's court. Generally speaking, once it is receipted by the two parties, the mediation statement becomes legally effective. That means that effect of a receipted mediation statement is identical to that of a final judgment regardless of whether the mediation statement is made at the stage of first or second instance. No appeal is possible against a mediation statement. However, if there is evidence that the mediation has violated the principle of voluntariness or that the content of the mediation agreement is in violation of the law, a retrial may be requested.

Although the CPL does not contain special provisions on mediation in international civil cases, the rules on domestic mediation must be deemed equally applicable to international cases provided the parties wish to resort to mediation.

\subsection{Mediation out of court}

Mediation out of court, or people's mediation, is deeply rooted in China and refers to mediation by a people's mediation commission. A people's mediation commission consists of 3 to 9 members who are elected by the people. Its activities must abide by the principle of lawfulness and that of voluntariness. The most distinct characteristic of people's mediation is that it has no legal effect. It is not a compulsory procedure to be followed before any litigation. When a dispute occurs, the parties may resort directly to the court if they are unwilling to try mediation by the people's mediation commission. Moreover, even if the parties have reached a conciliation agreement through mediation of

\footnotetext{
${ }^{124}$ Arts. 9, 85-91, 155 and 180 of the CPL contain provisions on mediation.

${ }^{125}$ See above, section 1.1.3.
} 
a people's mediation commission, they may still refuse to confirm the agreement and as yet bring a lawsuit to a people's court. 